\title{
PENGARUH SENAM JANTUNG SEHAT SERI-I TERHADAP DAYA TAHAN JANTUNG-PARU, KEKUATAN OTOT DAN KADAR TNF- $\alpha$ PLASMA PADA LANJUT USIA
}

\author{
Ajeng Fitria ${ }^{1}$, Leonardo Lubis ${ }^{2}$, Ambrosius Purba ${ }^{2}$ \\ ${ }^{\mathbf{1}}$ Fakultas Kedokteran, Universitas Padjadjaran, Bandung, Indonesia, \\ ${ }^{2}$ Departemen Anatomi, Fisilogi, dan Biologi Sel, Fakultas Kedokteran, Universitas Padjadjaran, Bandung, \\ Indonesia,
}

\begin{abstract}
The increasing number of elderly and elderly life expectancy is a challenge for health workers. Decreased cardiac endurance, muscle strength and increased incidence of inflammation will occur in the elderly as we get older. health cardio exercises series-I is an aerobic exercise that has moderate intensity and is carried out for 30 minutes, research is needed to analyze the effect on cardiac endurance, muscle strength and decrease plasma $T N F-\alpha$ levels in the elderly. Research design with experimental method, pre-test and posttest design approach. The study was conducted for 4 weeks on 25 samples which were divided into 3 groups of frequency of health cardio exercises series-I to measure endurance of the heart. A 6-minute road test and muscle strength were used for hand grip strength dynamometer, test back and leg dynamometer. Measurement of plasma TNF- $\alpha$ levels is carried out using the Elisa method. The data was then analyzed using paired t-test to see differences before and after health cardio exercises series-I. The results showed health cardio exercises series-I performed $3 x / m g$ can increase the heart's endurance compared to the frequency of $4 x / \mathrm{mg}$ and $5 \mathrm{x} / \mathrm{mg}(-16.11 \mathrm{vs} 15.62 \mathrm{vs}-47.62$ meters). health cardio exercises series-I frequency of $3 x / \mathrm{mg}$ and $4 x / \mathrm{mg}$ can increase back muscle strength ( $p$ value $=0.019, p<0.05$ ) and the frequency of $5 x / \mathrm{mg}$ can increase the strength of attractive shoulder muscles. $(p$-value $=0.033, p<0.05)$. Health cardio exercises series-I performed $3 x / m g, 4 x / m g$ and $5 x / m g$ did not have a significant effect on plasma TNF- $\alpha$ protein expression in the elderly (0.506 vs 0.856 vs. $0.382, p<0.05)$. It is suggested that the elderly can do I-1 series heart exercise with a frequency of $3 x / \mathrm{mg}$ to increase the heart's lung endurance and back muscle strength, a health cardio exercises series-I $4 x / \mathrm{mg}$ series to increase muscle strength of the back back, a series of health cardio exercises series-I frequency of $5 \mathrm{x} / \mathrm{mg}$ to increase attractive shoulder muscle strength.
\end{abstract}

Keywords:cardiorespiratory endurance, plasma tnf- $\alpha$ levels, muscle strength, $i$-heart healthy gymnastics series. 


\section{PENDAHULUAN}

Peningkatan usia harapan hidup (UHH) merupakan salah satu indikator keberhasilan pembangunan di bidang kesehatan. Sasaran rencana strategis Kementerian Kesehatan tahun 2010-2014 telah berhasil meningkatkan UHH lansia dari 70,7 tahun menjadi 72 tahun. Hasil Survei Sosial Ekonomi Nasional (Susenas) tahun 2000, jumlah lansia di Indonesia 14,4 juta orang atau $7,18 \%$ dari total jumlah penduduk, sedangkan pada tahun 2010 jumlah lansia mencapai 19 juta orang atau sekitar $8,5 \%$ jumlah penduduk. Hal ini menunjukkan peningkatan jumlah lansia yang diprediksi tahun 2020 diperkirakan meningkat sebesar 28,8 juta orang. Semakin meningkatnya jumlah lansia setiap tahun memerlukan pelayanan kesehatan yang optimal agar penambahan jumlah lansia tidak membebani biaya kesehatan Indonesia. UHH lansia yang semakin meningkat di Indonesia memerlukan penyediaan pelayanan kesehatan yang memadai.

Usia lansia yang semakin bertambah meyebabkan penurunan fungsi organ tubuh. Penurunan fungsi organ tubuh pada lansia ditandai dengan penurunan kebugaran jasmani yaitu berupa penurunan daya tahan jantungparu dan kekuatan otot. Penurunan fungsi daya tahan jantung paru lansia oleh karena otot jantung mengalami proses degeneratif, ukuran jantung mengecil, kekuatan memompa darah berkurang, pembuluh darah mengalami kekakuan. Selain itu ditemukan pula elastisitas pembuluh darah menurun yang menyebabkan peningkatan tahanan perifer dan tekanan darah. Ditemukan pula pada lansia adanya penurunan isi sekuncup dan curah jantung. Rangsangan impuls dari sino atrial node menurun sehingga menyebabkan penurunan denyut jantung maksimal. Selain penurunan daya tahan jantung paru ditemukan pula penurunan fungsi paru oleh karena elastisitas paru menurun, sehingga menyulitkan lansia untuk bernafas.

Menurut American college of sport medicine (ACSM), olahraga untuk meningkatkan derajat kebugaran jasmani adalah olahraga yang dilakukan dengan frekuensi 3-5x/minggu, intensitasnya sedang $(60-75 \%$ dari denyut nadi maksimal), jenis olahraga aerobic dan lama latihan 30-60 menit.Akhir-akhir ini Yayasan Jantung Indonesia memasyarakatkan senam Jantung Sehat Seri-I. Senam Jantung Sehat Seri-I (SJSS-I)kemungkinan lebih sesuai untuk lansia karena sesuai dengan olahraga untuk meningkatkan derajat kebugaran jasmani dan berdasarkan analisis gerak temponya lebih lambat, gerakannya mudah dilakukan, durasi pelaksanaan latihan pemanasan 10 menit, latihan inti bersifat aerobik 30 menit dan pendinginan 10 menit. Selain meningkatkan daya tahan jantung paru dan kekuatan otot, berdasarkan analisis gerak SJSS-I kemungkinan juga dapat menurunkan terjadinya peradangan yang ditandai dengan kadar TNF- $\alpha$ di plasma darah. Akan tetapi hasil penelitian terdahulu belum menunjukkan hasil yang konsisten tentang pengaruh olahraga terhadap perubahan kadar TNF- $\alpha$ pada lansia.

\section{METODE PENELITIAN}

Penelitian dilakukan dari bulan Juli- Agustus 2018dengan menggunakan data primer hasil pengukuran komponen fisik fisiologis, daya tahan jantungparu, kekuatan otot dan kadarTNFaplasma dari kondisi fisiklansia yang dilakukan oleh peneliti. Subjek penelitian adalah lansia sehat berusia 64-75 tahun yang tinggal di Balai Perlindungan Sosial Tresna Werdha (BPSTW) Ciparay Bandung Jawa Barat dengan kriteria inklusi berupa lansia sehat berusia 64-75 tahun yang tinggal di BPSTW Ciparay, data komponen fisik predominan dari kondisi fisik yang terdiri dari kekuatan, daya tahan jantungparu,kekuatan otot dan kadar TNF-aplasma lengkap. Total subjek penelitian ini adalah dua puluh lima lansia yang tinggal di BPSTW Ciparay yang terdiri dari tiga belas perempuan lansia dan dua belaslaki-laki lansia.

Data primer komponen fisik dari lansia diambil menggunakan alat ukur berupa hand grip strength dynamometer, test back dan push-pull dynamometeruntuk mengukurkekuatan otot; tes jalan 6 menituntuk mengukur daya tahan jantungparu; tes Elisauntuk mengukur kadar TNFaplasmalansia. Besarnya ukuran sampel diperkirakan berdasarkan tujuan penelitian yaitu mengetahui penerapan SJSS-I lansia terhadap daya tahan jantung paru dan kadar TNF-aplasma.

Rancangan penelitian dengan metode experimental,pendekatan pre-test dan post testdesign. Perlakuan yang diberikan dalam hal ini adalah perlakuan senam jantung sehat seri-I. Peneliti terlebih dahulu menentukan intensitas dan frekuensi senam jantung sehat seri-I untuk lansia berusia 64-75 tahun. 


\section{HASIL PENELITIAN}

Jumlah sampel pada penelitian ini adalah dua puluh lima subjek penelitian. Tabel 1 menunjukkan karakteristik Subjek berdasarkan Jenis Kelamin, Usia, Riwayat Pendidikan.

Tabel 4.1 Karakteristik Fisikfisiologis Berdasarkan Jenis Kelamin, Usia dan Riwayat Pendidikan

\begin{tabular}{lll}
\hline Karakteristik & Kategori & F \\
\hline Jenis kelamin & Perempuan & 13 \\
& Laki-laki & 12 \\
& Total & $\mathbf{2 5}$ \\
\hline Usia & $<70$ tahun & 12 \\
& $\geq 70$ tahun & 13 \\
& Total & $\mathbf{2 5}$ \\
\hline Riwayat & Tidak Sekolah & 4 \\
Pendidikan & SD & 7 \\
& SMP & 5 \\
& SMA & 5 \\
& Perguruan & 4 \\
& Tinggi & \\
& Total & $\mathbf{2 5}$ \\
\hline
\end{tabular}

$\mathrm{F}=$ frekuensi $\%=$ persentase

Berdasarkan tabel 4.1 menunjukkan bahwa lansia yang berjenis kelamin perempuan yaitu sebanyak $52 \% \quad(\mathrm{n}=13)$, sedangkan lansia yang berjenis kelamin laki-laki yaitu sebanyak 48\% $(\mathrm{n}=12)$. Berdasarkan data dari 25 responden yang merupakan Lansia di Balai Perlindungan Sosial Tresna Werdha (BPSTW) Ciparay diperoleh data responden berdasarkan karakter fisikfisiologis mengenai daya tahan jantungparu, kadar TNF- $\alpha$ plasma, kekuatan otot, denyut nadi istirahat, tinggi badan, berat badan, denyut nadi maksimal tercantum pada tabel 4.2 .

Tabel 4.2 Karakteristik Fisikfisiologis Berdasarkan Daya Tahan Jantungparu, Kadar TNF- $\alpha$ Plasma, Kekuatan Otot, Denyut Nadi Istirahat, Tinggi Badan, BeratBadan, Denyut Nadi Maksimal

\begin{tabular}{lccccc}
\hline Variabel & N & Min & Max & Mean & $\begin{array}{c}\text { Std } \\
\text { Dev. }\end{array}$ \\
\hline $\begin{array}{l}\text { Daya Tahan } \\
\text { JantungParu }\end{array}$ & 25 & 137.00 & 500.00 & 364.28 & 104.67 \\
$\begin{array}{l}\text { Genggaman } \\
\text { Tangan }\end{array}$ & 25 & .00 & 38.10 & 19.52 & 10.42 \\
$\begin{array}{l}\text { Kanan } \\
\text { Genggaman }\end{array}$ & 25 & 6.60 & 41.70 & 19.36 & 8.31 \\
$\begin{array}{l}\text { Tangan Kiri } \\
\text { Otot bahu- }\end{array}$ & 25 & 4.00 & 26.00 & 11.62 & 5.46 \\
pull & & & & & \\
Otot bahu & 25 & 3.00 & 25.00 & 12.92 & 6.42 \\
\hline
\end{tabular}

\begin{tabular}{lccccc}
\hline \multicolumn{1}{c}{ Variabel } & N & Min & Max & Mean & $\begin{array}{c}\text { Std } \\
\text { Dev. }\end{array}$ \\
\hline push & & & & & \\
\hline $\begin{array}{l}\text { Otot } \\
\text { punggung }\end{array}$ & 25 & 11.50 & 92.00 & 35.45 & 16.31 \\
$\begin{array}{l}\text { TNF- } \alpha \\
\text { Plasma }\end{array}$ & 25 & 156.35 & 887.94 & 463.18 & 146.91 \\
$\begin{array}{l}\text { Denyut } \\
\text { Nadi }\end{array}$ & 25 & 56.00 & 93.00 & 77.16 & 9.55 \\
$\begin{array}{l}\text { Istirahat } \\
\text { Tinggi }\end{array}$ & 25 & 128.00 & 172.00 & 149.10 & 12.03 \\
$\begin{array}{l}\text { Badan } \\
\text { Berat }\end{array}$ & 25 & 33.00 & 70.00 & 49.64 & 10.47 \\
$\begin{array}{l}\text { Badan } \\
\text { Denyut }\end{array}$ & 25 & 56.00 & 93.00 & 77.16 & 9.55 \\
Nadi Max & & & & & \\
\hline
\end{tabular}

Hasil uji-t berpasangan tercantum pada tabel 4.3 menunjukkan senam jantung sehat seri-I frekuesni $3 \mathrm{x} / \mathrm{mg}$ dapat meningkatkan daya tahan jantung paru lansia, akan tetapi senam jantung sehat seri-I frekuensi $4 \mathrm{x} / \mathrm{mg}$ tidak meningkatkan daya tahan jantung paru sedangkan frekuensi $5 \mathrm{x} / \mathrm{mg}$ dapat meningkatkan daya tahan jantung paru namun nilainya lebih rendah dibandingkan frekuensi $3 \mathrm{x} / \mathrm{mg}(-106,11$ vs 15,62 vs $-47,62)$.

Tabel 4.3Pengaruh Senam Jantung Sehat SeriIBerdasarkan frekuensi $3 \mathrm{x} / \mathrm{mg}, 4 \mathrm{x} / \mathrm{mg}$, dan $5 \mathrm{x} / \mathrm{mg}$ Terhadap Daya Tahan Jantungparu.

\begin{tabular}{lccccl}
\hline Frekuensi & $\begin{array}{c}\text { Mean } \\
\text { Pre }\end{array}$ & $\begin{array}{c}\text { Mean } \\
\text { Post }\end{array}$ & \multicolumn{1}{c}{$\boldsymbol{\Delta}$} & Sig. & \multicolumn{1}{c}{ Ket. } \\
\hline $3 \mathrm{x} / \mathrm{mg}$ & 270.89 & 377 & -106.11 & 0.017 & $\begin{array}{l}\text { Signifikan } \\
\text { Tidak } \\
\text { signifikan }\end{array}$ \\
$5 \mathrm{mg} / \mathrm{mg}$ & 320.37 & 304.75 & 15.62 & 0.528 & \\
& 361.87 & 409.5 & -47.62 & 0.402 & $\begin{array}{l}\text { Tidak } \\
\text { signifikan }\end{array}$ \\
\hline
\end{tabular}

Hasil uji-t berpasangan tercantum pada Tabel 4.4 menunjukkan pemberian senam jantung sehat seri-I frekuensi $3 \mathrm{x} / \mathrm{mg}$ dan $4 \mathrm{x} / \mathrm{mg}$ dapat meningkatkan kekuatan otot punggung ( $\mathrm{p}$-value $=$ $0.019, \mathrm{p}<0,05)$ dan senam jantung sehat seri-I frekuensi $5 \mathrm{x} / \mathrm{mg}$ dapat meningkatkan kekuatan otot bahu menarik. (p-value $=0.033, p<0,05)$.

Hasil ujit berpasangan yang tercantum pada tabel 4.5. menunjukkan senam jantung sehat seri-I yang dilakukan $3 x / \mathrm{mg}, 4 x / \mathrm{mg}$ dan $5 \mathrm{x} / \mathrm{mg}$ tidak memberikan pengaruh yang signifikan terhadap ekspresi protein TNF- $\alpha$ plasma pada lansia, namun apabila dilihat dari perbedaan kadar sebelum dan sesudah dilakukan senam jantung sehat seri-I frekuensi $3 \mathrm{x} / \mathrm{mg}$ dapat menurunkan ekspresi protein TNF- $\alpha$ plasma pada lansia lebih tinggi dibandingkan frekuensi $4 \mathrm{x} / \mathrm{mg}$ dan $5 \mathrm{x} / \mathrm{mg}$ (31.49 VS-9.94 VS-62.73). 
Tabel 4.4 Pengaruh Senam Jantung Sehat Seri-I yang Dilakukan 3x/mg, 4x/mg dan $5 x / m g$ terhadap Kekuatan Otot pada Lansia

\begin{tabular}{|c|c|c|c|c|c|c|}
\hline Frekuensi & Variabel & Mean Pre & $\begin{array}{l}\text { Mean } \\
\text { Post } \\
\end{array}$ & $\Delta$ & Sig. & Ket. \\
\hline \multirow{5}{*}{$3 \mathrm{x} / \mathrm{mg}$} & $\begin{array}{l}\text { Kekuatan } \\
\text { Genggaman } \\
\text { Tangan } \\
\text { Kanan }\end{array}$ & 16.15 & 19.01 & -2.86 & 0.086 & $\begin{array}{l}\text { Tidak } \\
\text { Signifikan }\end{array}$ \\
\hline & $\begin{array}{l}\text { Kekuatan } \\
\text { genggaman } \\
\text { tangan kiri }\end{array}$ & 17.95 & 17.81 & 0.14 & 0.876 & $\begin{array}{l}\text { Tidak } \\
\text { Signifikan }\end{array}$ \\
\hline & $\begin{array}{l}\text { Kekuatan } \\
\text { otot bahu } \\
\text { menarik }\end{array}$ & 8.78 & 9.94 & -1.17 & 0.219 & $\begin{array}{l}\text { Tidak } \\
\text { Signifikan }\end{array}$ \\
\hline & $\begin{array}{l}\text { Kekuatan } \\
\text { otot bahu } \\
\text { mendorong }\end{array}$ & 12.22 & 13.11 & -0.89 & 0.347 & $\begin{array}{l}\text { Tidak } \\
\text { Signifikan }\end{array}$ \\
\hline & $\begin{array}{l}\text { Kekuatan } \\
\text { otot } \\
\text { punggung }\end{array}$ & 26.05 & 28.72 & -2.67 & 0.019 & Signifikan \\
\hline \multirow{5}{*}{$4 x / m g$} & $\begin{array}{l}\text { Kekuatan } \\
\text { Genggaman } \\
\text { Tangan } \\
\text { Kanan }\end{array}$ & 20.05 & 17.03 & 3.01 & 0.457 & $\begin{array}{l}\text { Tidak } \\
\text { Signifikan }\end{array}$ \\
\hline & $\begin{array}{l}\text { Kekuatan } \\
\text { genggaman } \\
\text { tangan kiri }\end{array}$ & 21.31 & 21.15 & 0.16 & 0.913 & $\begin{array}{l}\text { Tidak } \\
\text { Signifikan }\end{array}$ \\
\hline & $\begin{array}{l}\text { Kekuatan } \\
\text { otot bahu } \\
\text { menarik }\end{array}$ & 11.75 & 11.62 & 0.12 & 0.802 & $\begin{array}{l}\text { Tidak } \\
\text { Signifikan }\end{array}$ \\
\hline & $\begin{array}{l}\text { Kekuatan } \\
\text { otot bahu } \\
\text { mendorong }\end{array}$ & 11 & 13.37 & -2.37 & 0.090 & $\begin{array}{l}\text { Tidak } \\
\text { Signifikan }\end{array}$ \\
\hline & $\begin{array}{l}\text { Kekuatan } \\
\text { otot } \\
\text { punggung }\end{array}$ & 37.62 & 41.99 & -5.36 & 0.008 & Signifikan \\
\hline \multirow{5}{*}{$5 \mathrm{x} / \mathrm{mg}$} & $\begin{array}{l}\text { Kekuatan } \\
\text { Genggaman } \\
\text { Tangan } \\
\text { Kanan }\end{array}$ & 22 & 22.58 & -0.58 & 0.728 & $\begin{array}{l}\text { Tidak } \\
\text { Signifikan }\end{array}$ \\
\hline & $\begin{array}{l}\text { Kekuatan } \\
\text { genggaman } \\
\text { tangan kiri }\end{array}$ & 18.75 & 19.32 & -0.57 & 0.700 & $\begin{array}{l}\text { Tidak } \\
\text { Signifikan }\end{array}$ \\
\hline & $\begin{array}{l}\text { Kekuatan } \\
\text { otot bahu } \\
\text { menarik }\end{array}$ & 11 & 13.50 & -2.50 & 0.033 & Signifikan \\
\hline & $\begin{array}{l}\text { Kekuatan } \\
\text { otot bahu } \\
\text { mendorong }\end{array}$ & 11.12 & 12.25 & -1.12 & 0.562 & $\begin{array}{l}\text { Tidak } \\
\text { Signifikan }\end{array}$ \\
\hline & $\begin{array}{l}\text { Kekuatan } \\
\text { otot } \\
\text { punggung }\end{array}$ & 32.37 & 35.50 & -3.13 & 0.110 & $\begin{array}{l}\text { Tidak } \\
\text { Signifikan }\end{array}$ \\
\hline
\end{tabular}


Tabel 4.5 Pengaruh Senam Jantung Sehat Seri -I Berdasarkan frekuensi $3 x / \mathrm{mg}, 4 x / \mathrm{mg}$, dan $5 x / \mathrm{mg}$ terhadap Kadar TNF- $\alpha$ plasma

\begin{tabular}{|c|c|c|c|c|c|}
\hline Frekuensi & $\begin{array}{c}\text { Mean } \\
\text { Pre }\end{array}$ & $\begin{array}{c}\text { Mean } \\
\text { Post }\end{array}$ & $\Delta$ & Sig. & Ket. \\
\hline $3 \mathrm{x} / \mathrm{mg}$ & 425.38 & 393.89 & 31.49 & 0.506 & $\begin{array}{l}\text { Tidak } \\
\text { Signifikan }\end{array}$ \\
\hline $4 x / m g$ & 443.32 & 453.26 & -9.94 & 0.856 & $\begin{array}{l}\text { Tidak } \\
\text { signifikan }\end{array}$ \\
\hline $5 \mathrm{x} / \mathrm{mg}$ & 488.35 & 488.35 & -62.73 & 0.382 & $\begin{array}{l}\text { Tidak } \\
\text { signifikan }\end{array}$ \\
\hline
\end{tabular}

\section{DISKUSI}

Dari hasil penelitian berdasarkan hasil penelitian uji-t berpasangan ditemukan senam jantung sehat seri-I yang dilakukan tiga kali perminggu lebih baik untuk meningkatkan daya tahan jantungparu dibandingkan dengan senam yang dilakukan empat kali perminggu dan lima kali perminggu. (377 vs 304,75 vs 409,5 meter). Adanya pengaruh latihan senam jantung sehat seriI pada lansia dengan frekuensi tiga kali seminggu lebih baik dibandingkan dengan frekuensi senam jantung sehat seri-I empat kali seminggu dan frekuensi lima kali seminggu berkaitan dengan training effect (pengaruh latihan) terhadap respon adaptasi fisiologis dari fungsi paru, darah, jantung, dan pembuluh darah.

Latihan daya tahan aerobik yang teratur, salah satunya senam jantung sehat seri-I memicu perubahan metabolik didalam serat otot oksidatif, bertambahnya serat otot, mitokondria dan jumlah kapiler yang menyalurkan darah ke serat-serat otot. Otot-otot yang telah beradaptasi menggunakan $\mathrm{O}_{2}$ secara lebih efesien dan hal ini menyebabkan daya tahan umum jantungparulansia bisa lebih baik dan tidak cepat mengalami kelelahan pada saat melakukan aktivitas fisik yang relatif lama. Selain itu latihan jantungparudapat pula meningkatkan pembentukan antioksidan, endogen dan kemampuan otot lansia yang terlatih untuk mengeliminasi asam laktat di otot.

Latihan aerobik yang rutin dengan frekuensi, intensitas dan lama latihan yang terukur dan terprogram dengan baik dapat meningkatkan daya tahan jantung paru. latihan aerobik akan menyebabkan terjadinya adaptasi fisiologis dari fungsi paru, jantung, pembuluh darah dan otot. Efek senam SJSS-I pada anatomis otot dapat menyebabkan hipertropi baik pada serabut otot lambat (slow twist) maupun serabut otot cepat (fast twist). Pada otot yang mengalami hipertropi, serabutnya akan bertambah dan juga jumlah kapiler akan meningkat, sehingga darah yang kaya oksigen $\left(\mathrm{O}_{2}\right)$ akan banyak dipompakan pada serabut otot yang aktif saat latihan. Kualitas dari hipertropi oleh kekuatan kontraksi otot pernafasan dalam menstabilkan tulang dada, rangka dada dan memperbesar pengembangan rongga dada.

Latihan SJSS-I akan menyebabkan perubahan pada system otot pernafasan terjadi peningkatan myoglobin atau pigmen pengikat oksigen dalam otot yang berfungsi sebagai penimbun oksigen, peningkatan oksidasi karbohidrat, latihan SJSS-I dapat meningkatkan kapasitas otot untuk mengubah glikogen menjadi $\mathrm{CO}_{2}$ dan $\mathrm{H}_{2} \mathrm{O}$ serta ATP dengan pertolongan oksigen. Latihan fisik seperti senam aerobik dapat mengakibatkan perubahan pada sistem kardiovaskuler baik secara anatomi maupun fisiologis. Bertambahnya ukuran jantung akan mengakibatkan jantung semakin efisien dalam memompakan darah. Hal ini secara langsung menyebabkan frekuensi denyut jantung dengan penurunan frekuensi jantung, maka jantung memiliki cadangan denyut jantung (Heart Rate reserve) yang lebih tinggi. Penurunan frekuensi jantung oleh: bradikardia, peningkatan tonus simpatis atau kombinasi dari kedua hal ini, juga frekuensi pengeluaran impuls dari jantung. Hal ini mengakibatkan stroke volume menjadi lebih besar, sehingga HRR meningkat, maka cardiac output (curah jantung) akan lebih tinggi. Peningkatan oksigen menjadi lebih tinggi jika terjadi peningkatan jumlah kapiler yang menyalurkan oksigen pada otot yang lebih aktif.

Kekuatan dan ketahanan otot, untuk mengurangi penurunan fungsi otot, pemberian rangsangan yang adekuat terhadap sejumlah otototot besar pada lansia mutlak dilakukan. Lansia dengan otot yang kuat berisiko lebih kecil untuk terjatuh, karena kelemahan otot terutama mengenai otot penopang berat badan. Pelatihan senam jantung sehat seri-I ditujukan terutama pada otototot besar. SJSS-I adalah olahraga yang disusun dengan selalu mengutamakan kemampuan jantung dan gerakan otot besar serta memiliki banyak manfaat dan kelebihan yaitu memberikan koordinasi yang baik, memperbaiki postur tubuh, meningkatkan kekuatan otot pada lansia, berupaya memasukkan oksigen sebanyak mungkin, murah meriah, praktis, serta aman dilakukan.

Peningkatan kadar TNF- $\alpha$ plasma yang bersifat inflamasi dapat merusak endotel pembuluh darah jantung maupun otak atau kerusakan sel beta pancreas maupun reseptor insulin.TNF- $\alpha$ adalah sitokin yang diketahui memediasi kerusakan sistem muskuloskeletal dan sistem imun. TNF- $\alpha$ adalah 
sitokin pro-inflamasi yang memediasi proses peradangan dan penyembuhan.Namun ketika dilepaskan secara berlebihan, TNF- $\alpha$ dapat pula menyebabkan peradangan yang dapat memperparah proses peradangan yang terjadi sebelumnya, hal ini terjadi seperti pada beberapa penyakit kronis pada lansia.Pemberian SJSS-I yang terukur dan terprogram dengan baik yang dilakukan $3 \mathrm{x} / \mathrm{mg}$ dari hasil penelitian menunjukkan kadar TNF- $\alpha$ plasma lebih rendah dibandingkan dengan senam jantung sehat seri-I yang dilakukan $4 x / \mathrm{mg}$ dan $5 \mathrm{x} / \mathrm{mg}$.

\section{KESIMPULAN}

Berdasarkan hasil penelitian dan pembahasan dapat di ambil kesimpulan sebagai berikut:

1) Senam jantung sehat seri-I frekuensi 3 kali perminggu dapat meningkatkan daya tahan jantungparu pada lansia.

2) Senam jantung sehat seri-I frekuensi $3 x / m g$ dan $4 \mathrm{x} / \mathrm{mg}$ dapat meningkatkan kekuatan otot punggung dan frekuensi $5 \mathrm{x} / \mathrm{mg}$ dapat meningkatkan kekuatan otot bahu menarik

3) Senam jantung sehat seri-I yang dilakukan $3 \mathrm{x} / \mathrm{mg}, 4 \mathrm{x} / \mathrm{mg}$ dan $5 \mathrm{x} / \mathrm{mg}$ tidak memberikan pengaruh yang signifikan terhadap kadar TNF- $\alpha$ plasma pada lansia, namun apabila dilihat dari perbedaan kadar sebelum dan sesudah dilakukan senam jantung sehat seri-I frekuensi $3 \mathrm{x} / \mathrm{mg}$ dapat menurunkan ekspresi protein TNF- $\alpha$ plasma pada lansia lebih tinggi dibandingkan frekuensi $4 \mathrm{x} / \mathrm{mg}$ dan $5 \mathrm{x} / \mathrm{mg}$.

\section{DAFTAR PUSTAKA}

1. RI KK. Infodatin (situasi lanjut usia (lansia) di Indonesia. Jakarta Selatan: Pusat Data Informasi Kementrian Kesehatan RI; 2016.

2. Pradnyandari NKD, Diniari NKS. Perbandingan Kejadian dan Status Depresi Lansia yang Tinggal Bersama Keluarga dengan yang Tinggal di Panti Sosial Tresna Werdha Wana Seraya Denpasar Bali. J Med Udayana. 2014;3(7):2303-1395.

3. Fajemiroye JO, Cunha LC, Rodriguez RS, Rodrigues KL, Naves LM,Mourão AA, et. al. Aging-Induced Biological Changes and Cardiovascular Diseases. Biomed Res Internat. 2018;4(1):1-14.

4. Boros K, Freemont T. Physiology of Ageing of The Musculoskeletal System. Best practice \& Res Clin Rheumatol. 2017;31(2):1-15.

5. Gjestvang C, Stensrud T, Haakstad LAH. How is Rating of Perceived Capacity Related to $\mathrm{VO}_{2}$ max and What is $\mathrm{VO}_{2} \max$ at Onset of Training. BMJ J. 2017;3(1):1-7.
6. Park E, Meininger JC, Kang DH, Gabriel KP, Padhye NS. Association of Cardiorespiratory Fitness and Adiposity with Inflammatory Biomarkers in Young Adults. Am J Hum Biol. 2017;29(3):1-10.

7. Massy-Westropp N, Gill TK, Taylor AW, Bohannon RW, Hill CL. Hand Grip Strength: Age and Gender Stratified Normative Data in a Population- Based Study. BMC Res Notes. 2011;4(127):1-5.

8. Van Harlinger W, Merrit JL. Upper Limb Strenght: Study Providing Normative Data for a Clinical handled Dynamometer. Original Res PMR. 2015:135-140.

9. Vijayaraghava A, Doreswamy V. Exercise and The Cytokine-Interlukin-6 (IL-6) and Tumor Necrosis Factor- $\alpha$ (TNF- $\alpha)$ : A Review. Ann Med Physiol. 2017;1:3-8.

10. Kilapong RBJD, Supit S, Rampengan JJV. Pengaruh Latihan Beban pada Lansia terhadap kadar TNF- $\alpha$. J e-Biomed. 2015;3(3):681-685.

11. Supit IA, Pangemanan DHC, Marunduh SR. Profil Tumor Necrosis Factor (TNF- $\alpha)$ Berdasarkan Indeks Massa Tubuh (IMT) pada Mahasiswa Fakultas Kedokteran UNSRAT Angkatan 2014. $J$ e-Biomed.2015;3(2):640643.

12. Vijayaraghava A, Doreswamy V, Narasipur OS, Kunnavil R, Srinivasamurthy N. Effect of yoga practice on levels of inflammatory markers after moderate and strenuous exercise. J Clin Diagn Res. 2015;9(6):8-12.

13. Jahromi AS, Zar A, Ahmadi F, Krustrup P, Ebrahim K, Hovanloo F, et. al. Effect of Endurance Training on the Serum Levels of Tumour Necrosis Factor- $\alpha$ and Interferon- $\gamma$ in Sendentary Men. Immune Netw. 2014;14(5):255-259.

14. Flores TR, Gomes AP, Soares ALG, Nunes BP, Assunção MCF, Gonçalves $\mathrm{H}$, et. al. Counseling by Health Professionals and Healthy Behaviours Among The Elderly: Population-Based Study in Pelotas, South of Brazil 2014. Epidemiol Serv Saud. 2018;27(1):1-10.

15. Buku Senam Jantung Sehat Seri I. Jakarta: Yayasan Jantung Indonesia; 2003. 